
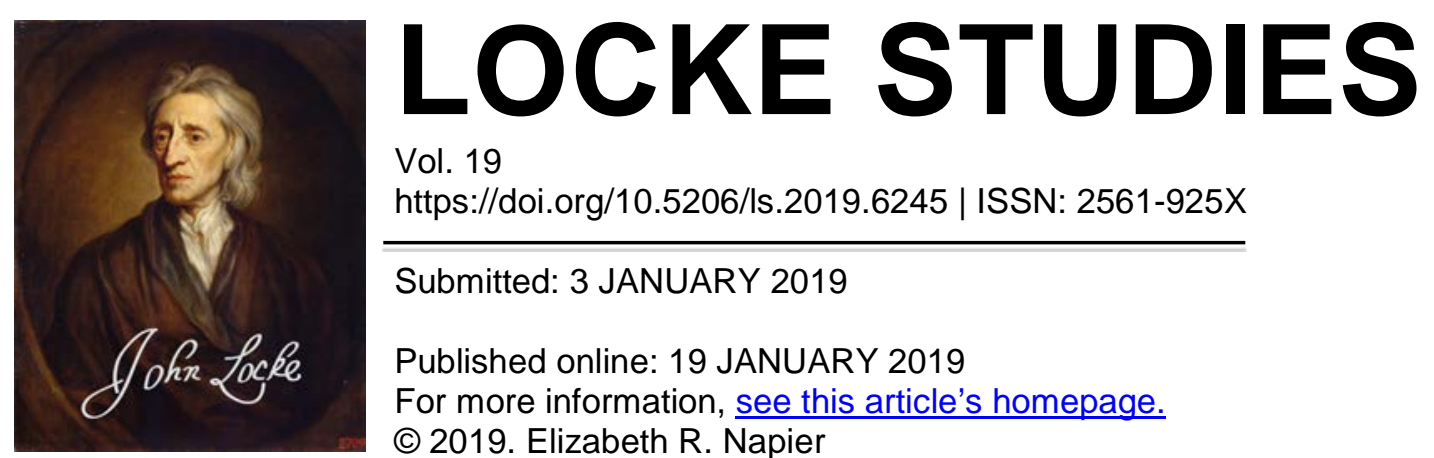

Vol. 19

https://doi.org/10.5206/ls.2019.6245 | ISSN: 2561-925X

Submitted: 3 JANUARY 2019

Published online: 19 JANUARY 2019

For more information, see this article's homepage.

(c) 2019. Elizabeth R. Napier

\title{
Review of Daniel Defoe and the Representation of Personal Identity by Christopher Borsing
}

\section{ELIZABETH R. NAPIER (MIDDLEBURY COLLEGE)}

Abstract: A review of Christopher Borsing's recent book, Daniel Defoe and the Representation of Personal Identity (London and New York: Routledge, 2017).

Keywords: Daniel Defoe, personal identity, self, conduct book, eighteenth-century novel 
Borsing, Christopher. Daniel Defoe and the Representation of Personal Identity. London and New York: Routledge, 2017. Routledge Studies in Eighteenth-Century Literature, 13. 202 pp. \$150 (hbk); \$49.95 (pbk). ISBN 9781848934832 (hbk); ISBN 9780367175658 (pbk). Ebook available.

\section{Reviewed by ELIZABETH R. NAPIER}

Christopher Borsing argues that Defoe represents personal identity "as the experience of privileged subjectivity within a shared world" (1). In so doing Borsing joins scholars such as Michael McKeon, who emphasizes the rise of privacy in the eighteenth century (The Secret History of Domesticity [Baltimore, MD: J ohns Hopkins University Press, 2005]), and Dror Wahrman (The Making of the Modern Self [New Haven, CT: Yale University Press, 2004]), who charts the gradual interiorization and individuation of self in the period. Interested primarily in the friction between private (or assumed) identity and the public sphere, Borsing tests this idea against Defoe's personal career of disguise and subterfuge and against a selection of diverse texts by Defoe: The True-Born Englishman, The Family Instructor, Robinson Crusoe, Captain Singleton, Moll Flanders, Roxana, A J ournal of the Plague Year, The Political History of the Devil, and An Essay on the History and Reality of Apparitions. In The Family Instructor and in the novels, those works most amenable to discussions of representations of personal identity, assertion of an autonomous self is enacted against a backdrop of received notions of authority and conformity (social, political, or religious). In each of these works, Borsing calls attention to the difficulties of establishing credible authority within autobiographical narratives and concomitantly of the challenges of reading such works.

In The True-Born Englishman and The Family Instructor, public (national or spiritual) identity and the private self are situated antagonistically, with Defoe, in The True-Born Englishman, adopting a "hybrid" narrative persona in his apologia for the Dutch William III that challenges a reader's belief in a "pure" English national identity. The Family Instructor depicts a series of more fully elaborated splits between public and private in a domestic context, in dramatizations of dysfunctional family dynamics revolving around contested notions of hierarchy and religious expression. The vignettes feature disruptive expressions of self within the family, often on the part of children whose innocent remarks expose fault lines in conventional enactments of religious fealty. Such episodes function to challenge paternal authority beneath a façade of domestic harmony or shared familial identity, implicitly creating space for personal autonomy. Though Defoe is not an outward proponent of dissidence (as much as he embraces it to create drama and energy in his narratives), an interesting pattern in these pieces is that those of a lower status-children, wives, servants - are increasingly shown to be desirous of asserting authority over their own lives. Borsing argues, too, that Defoe aims in The Family Instructor to engage readers in ways that are innovative for the conduct book genre and that look forward to the imaginative investment that plays a role in expanding the definition of self in Robinson Crusoe, Moll Flanders, and Roxana.

In Robinson Crusoe, Defoe further elaborates on the theme of filial disobedience, exploring, punishing, and rewarding Crusoe's expressions of insubordination in his attempts at self-determination, underscoring the fact that, as Nancy Armstrong has argued (How Novels Think [New York: Columbia University Press, 2005], 34-35), the individual is offered refuge within the community only at the expense of certain liberties 
of movement and expression. "Split" or "alternative" selves are created to stabilize an identity in isolation or in peril, though Borsing alludes to this interesting ontological project and its impact on Defoe's audience with frustrating obliqueness. Borsing then moves on to a more spirited discussion of Captain Singleton, arguing that Bob, one of Defoe's most interesting fictional creations, portrays little coherence as a character and a curious disengagement with his past or present. Bob's diffidence and anomie suggest a virtual untethering from a self that could serve as a stable field of reference for anything, a point that Borsing makes well, though it could be elaborated in much fuller detail.

Moll Flanders and Roxana are then treated as more extreme "fictions of identity" (114) in light of the escalation and deepening of the project of disguise in these purported autobiographical narratives. Moll's reliance on lies and fictional accounts of her person qualifies her-as does Roxana's sustained masquerade-for a more concentrated treatment of the themes of public pressure and of the negotiations on the basis of which her "self" is repeatedly refashioned. In the course of his discussion of both of these novels, Borsing claims that in the project of "self-remaking," as Charles Taylor has called it (Sources of the Self [Cambridge MA: Harvard University Press, 1989], 171), the reader has little basis upon which to test the truth of Moll's or Roxana's account. These claims are overstated. All Defoe's narrators conceal and obfuscate - and the reader is made fully aware that they are doing so-but it is not finally helpful to make the vague claim that "Moll is present only as unreliable and indeterminate information" (131), a point that Borsing also makes vis à vis narration in Roxana and that seems on occasion to beg the very question of his inquiry. In his analysis of Roxana, furthermore, Borsing gets sidetracked by Geoffrey Sill's weird argument about Susan's parentage ("Roxana's Susan: Whose Daughter Is She Anyway?," Studies in Eighteenth-Century Culture 29 [2000]), downplaying the intensely disturbing relationship between Roxana and Amy first explored by Terry Castle, which surely sheds a more lurid light on the displacement of agency (which has centrally to do with boundaries of the self in this novel of criminal action) than on uncertain identities leading to a kind of readerly distrust

In his final chapter, Borsing discusses the workings of Providence and the Devil (who seems to be on intimate terms with many of Defoe's characters) and spectral or apparitional identity in the context of A J ournal of the Plague Year, An Essay on the History and Reality of Apparitions, and The Political History of the Devil, with renewed attention to Moll Flanders and Roxana, in which ghostly events similarly play a role. Conjointly, he draws a parallel between spirit-possession and the act of reading.

Borsing's analysis of the representation of personal identity in Defoe's work leaves the reader wishing for a more focused and sustained analysis of this fascinating topic. Borsing repeatedly gets side-tracked, however, into less directly relevant areas of inquiry, namely the world of financial credit and issues of readership and print, which he fails to tie solidly to the subject of his study. While stock markets may have given rise to projections of self that were unmoored from reality and while the exchange economy may have necessitated negotiation, does it therefore follow that notions of the self become fictionalized and/ or contractual? Such points, rather than being carefully developed and applied thoughtfully to the texts under consideration, are made in passing with no real engagement with the issues of identity that Borsing suggests are his main concern. Thus, the reader wades through much descriptive material about Defoe's work and its contexts without getting to the core of Borsing's thesis. Subjects of inquiry that are parallel-among them in particular the issues of readership - are not proved by Borsing to be integral to his quest 
to explicate the way in which Defoe represents personal identity in his works, however frequently he recurs to such topics. Defoe's characters cannot simply, for example, be written off as "experiments in textual simulacra" (10). All novelistic characters are imagined, "instrumental fiction[s] that realize [themselves] through the imaginative narration" (84), so how is it helpful to make that claim in the absence, especially, of any sustained investigation of generic conventions? Borsing does comment on satire and spiritual autobiography, as well as travel, pirate, and criminal narratives, but he deliberately eschews discussion of the rise of the novel as a literary genre, a project that would seem to be crucial to any argument that posits that readers of Defoe's fictions engage characters in new or different ways or that their engagement with such characters implicitly endorses the subjectivity to which they aspire. "Defoe's works fascinate," claims Borsing, "because they experiment with the image of a private and autonomous individual at a time when such a concept was not yet settled into a normative truth" (173). Yet Borsing does not provide evidence for such a state of affairs, nor for his claim that personal identity is an imaginative construct on the part of the reader that bears financial fruit for the bookseller. His repeated use of the image of mirrors to suggest this sort of reflexivity does not help the matter. Plot summaries, often clotted language, drifting off the topic of personal identity, repeated typographical errors, critics' quotations that are attributed solely in endnotes make for difficult reading. Many potentially productive points - the notion of decomposed, depleted, and recycled identity in Robinson Crusoe among them-could fruitfully be examined in more detail. Remarks such as "The self is ... an instrumental fiction that realizes itself through imaginative narration" (84) or "Crusoe is not real but a literary homunculus borne in the mental bloodstream" (169) could be made of any fictional character. If Defoe represents a self under constant negotiation and interpretation, this must be shown indefatigably in the novels, not simply asserted to be true as an act of reading. The attention to Captain Singleton and The Family Instructor is merited and welcome. But even in his most interesting chapter (and the one most germane to a discussion of Locke's theories) the points made about Bob's identity occupy a mere two or three pages in a twenty-six-page chapter, shunted aside by discussions of Friend William, pirate narratives, and market forces.

Middlebury College 